\title{
Finance in Economic Growth: Eating the Family Cow
}

\author{
Peter Temin ${ }^{1}$
}

\section{Working Paper No. 86}

December 17, 2018

\begin{abstract}
The American economy changed rapidly in the last half-century. The National Income and Product Accounts (NIPA) were designed before these changes started. They have stretched to accommodate new and growing service activities, but they are still organized for an industrial economy. It is hard to fit finance into the measurement of national product and of economic growth, and similar problems bedevil efforts to include other intangible investments as well. I describe how our current accounts deal with these problems, and I argue that existing NIPA data fail to describe the future path of growth in our new economy because they lack output data on financial, human and social capital investments. They fail to show that the United States is

\footnotetext{
${ }^{1}$ Peter Temin is the Elisha Gray II Professor Emeritus at MIT. Contact: ptemin@mit.edu. He thanks Daman Cox, Vijay Khosa and Seth Markowitz of the BEA, Thomas Ferguson and Thomas Philippon for their help. He also thanks the Institute for New Economic Thinking (INET) for financial support. He claims all errors as his alone.
} 
consuming its capital stock now and will suffer later, rather like killing the family cow to have a steak dinner.

JEL Codes: B40, G19, N12

Keywords: NIPA, BEA, finance, economics growth, human capital, social capital 


\section{Introduction}

The American economy changed rapidly in the last half-century. We kept track of this transformation through the National Income and Product Accounts (NIPA), a set of statistical constructs that were designed before these changes started. Our national accounts have stretched to accommodate new and growing service activities, but they are still organized by their original design. This can be seen in the growth of financial activity and the efforts of many economists to fit finance into our measurement of national product and of economic growth. I argue in this paper that our current economic data fail to describe accurately the path of growth in our new economy. They fail to see that the United States is consuming its capital stock now and will suffer later, rather like killing the family cow to have a steak dinner.

Modern growth theory started with two papers by Robert M. Solow in the late 1950s. The first paper showed that it was possible to create a stable model of economic growth using a Keynesian model of investment and capital. The second paper showed that this model failed to explain most of American growth in the first half of the $20^{\text {th }}$ century (Solow, 1956, 1957).

Other economists expanded Solow's model by adding additional types of capital: human capital, social capital, financial capital. The first addition was to add human capital by measuring the effect of education on productivity. This enabled economists to work with an expanded Solow model. The second addition was to add social capital. This was added in crosssectional regressions and has not been applied to ongoing growth estimates. The third addition was added by assuming that wealth equals physical capital, that is, financial capital is 
indistinguishable from physical assets (Mankiw, Romer and Weil, 1992; Hall and Jones, 1999; Dasgupta, 2007; Piketty 2014).

These additions furnished explanations of economic growth in the United States and other countries. The importance of these contributions was confirmed in many empirical studies, but the NIPA continues to calculate Private Fixed Investment, a Keynesian construct, as the investment part of GDP. In other words, our national accounting has not caught up with the evolution of the economy and economic insights that have highlighted the importance of extraKeynesian investment.

This problem is acute in the data for finance. Philippon $(2015,1435)$ looked at the measurement of financial intermediation in the United States and concluded that, "The unit cost of financial intermediation does not seem to have decreased significantly in recent years." As he says, this is surprising on several grounds. I build on his work to understand whether this result is the result of how the underlying data were collected.

This disconnect infects the calculation of economic growth. Griliches $(1990,1994)$ noted over two decades ago that more and more of GDP is composed of services, which also have been called intangibles. It is hard to estimate the output of the financial sector, for example, so it is measured by its inputs. As I will show, although this may give a useful measure of current activity, it is less informative about economic growth.

There are two problems. It is hard to measure productivity if inputs and outputs are conflated. If we fail to include productivity growth of an increasing part of the national product, we increasingly will underestimate the growth of the national product. Further, if we do not have a good measure of output, it is almost impossible to measure investments in finance and other 
intangibles. If we do not have good measures of the various forms of capital listed here, we will not be able to think hard about longer-run growth. Concern about this latter point provides the motivation for this paper.

Outside the literature on the national product, there are many treatments of these new forms of capital. In addition to financial capital, human capital has been the center of explanations for the United States economic domination in the twentieth century as well as the progress of individuals within the United States (Golden and Katz, 2008; Heckman, Pinto and Savelyev, 2013). Social capital has been the center of analyses of economic growth in the United States and elsewhere and in the long and short run (Putnam, 1993, 2000; Dasgupta, 2007). Measuring these forms of capital poses many of the same problems as measuring financial capital.

I review in this paper the accounting methods used to compile investment data to understand how these other forms of capital behave in an economy that has changed markedly since the 1950s. I conclude that current accounting of growth in GDP fails to include the kind of investment that generates these other forms of capital. This conclusion has three implications. First, short-run growth as currently calculated bears more relation to short-run Keynesian analysis than to what we know about long-run economic growth. Second, financial capital increases inequality more than it generates growth for the entire economy. Third, we are now allowing human and social capital to depreciate, auguring ill for future economic growth in the United States.

I start this analysis in the next section by surveying the treatment of finance in empirical and conceptual work. I then generalize the treatment of financial capital to consider the 
measurement of all intangible capital. In the third section, I detail how we are consuming our capital, in its various forms: Keynesian, financial, human and social.

\section{Finance in economic growth}

To explore the role of finance in economic growth, it is useful to recall the history of finance for the last century, roughly from the Great Depression of 1929 to the Great Recession of 2008. The economy changed dramatically in the eighty years between these financial crises, and our information about the economy changed as well. It is hard to recall how little we knew of what we now call macroeconomics in the early 1930s, and we can get a glimpse of economists' confusion at the start of this decade by recalling a little-known British committee.

The British government assembled the Macmillan Committee in 1930 to help make sense of the developing financial and economic crisis. They called on the most prominent economist of the time, John Maynard Keynes, to lead discussions in this intellectual inquiry. Keynes rose to the challenge but was unable to make enough sense of what was happening to convince a single other member of the committee. He did however convince himself to keep trying to understand, and it took several years of work by him and his colleagues to do so (Temin and Vines, 2013; Keynes, 1936).

The United States government asked an American economist, Simon Kuznets, to figure out how to measure national production around the time Keynes published his new view of the economy. We can see in hindsight how these two projects supported each other, but they appeared quite independent at the time. Keynes and his students sought to conceptualize the 
economy as a whole. Kuznets and his colleagues were asked to define the details of measurement in order to produce an ongoing record of national production.

Looking backward, we can see that the economists in the 1930s needed to answer two related questions. What do we mean by national production? And how are production and unemployment related to finance and financial events?

It was clear from the start that while the measurement of production should be comprehensive, there were many choices that had to be made. For example, it seemed logical to exclude women's household work in the 1930s, although it may be less obvious now. This example reveals how social attitudes determined what was counted in national income.

The omission of housework contrasts with the inclusion of rental income from owneroccupied houses. People do not pay rent to themselves any more than they pay for household work by family members. But the argument was made that national product should not be affected by whether people owned or rented their living quarters. In the absence of internal family markets, the spending on owner-occupied housing was and still is imputed by looking at indirect evidence of the service being consumed: "The largest NIPA imputation is that made to approximate the values of the services provided by owner-occupied houses (US Department of Commerce, 2017, 2-5)." The contrast between these opposing decisions illustrates the problems we now face. The output of many services is hard to observe, and we impute outputs by looking at inputs.

For now, let us return to the emerging concept of production. Kuznets argued in a 1937 meeting, in a remark quoted often by recent critics of national accounts, "It would be of great value to have national income estimates that would remove from the total the elements which ... 
represent dis-service rather than service. Such estimates would subtract from the present national income ... a great many of the expenses involved in financial and speculative activities." (Kuznets 1937, 37; Coyle, 2014, 13-14; Pilling, 2018, 29-30).

This argument stands as a footnote to our intellectual history because Kuznets' data quickly came to be a tool in wartime planning. The aim was to use national product data to allocate resources during the Second World War rather than to consider whether the activities were "dis-service rather than service." Across the ocean, Keynes (1940) showed how national production could be redirected to military ends without impoverishing workers in How to Pay for the War. Neither Keynes nor Kuznets tried to argue for just wars or to follow up the latter's inclusion of some financial activities in dis-services.

These discussions and decisions provided a foundation on which Solow formulated a theory of growth after the war. While Keynes concentrated on how savings became equal to investments, Solow assumed they were equal to transform Keynes' short-run theory into a theory of economic growth. The United States Bureau of Economic Analysis (BEA) and its counterparts in other countries went along with this simplification and measured investment as private fixed physical assets. But they included financial activity in their calculation of national income and production.

The Bureau of Economic Analysis takes great care in the process of gathering data of economic activity. As in any complex operation, it has to group people into different activities for coherence and efficiency. This implies that the group that compiles income estimates is separate from the group that measures investment. The latter is thought of as changes in private fixed physical assets. As far as an outsider can tell, the coordination between the groups that 
compile national income and national production is limited to finding any "errors" that cause the efforts to differ despite the Keynesian accounting identity that says they are equal.

It may be well to review this Keynesian identity for those readers who have not taken macroeconomics recently. (I ignore government and foreign trade, both of which can be added easily.) From the product side: national product is the sum of consumption and investment. From the income side: national income is the sum of consumption and savings. We assume that national product and income are equal and equate the two relations. Note that consumption is on both sides of this relation and cancels out. That leaves investment equals savings. While there are several Keynesian insights, this may be the most important here (Temin and Vines, 2014.)

This equality creates tension between the descriptions of short-run and long-run concepts that can best be understood in Keynesian terms. Investment is counted as physical capital, but savings includes financial activities. This was not a big problem during the recovery from the Second World War when banking and finance were tightly controlled (Temin, 2002a). It increased in importance as the recovery ended in the stormy 1970s and finance began to be deregulated. It has grown rapidly since then, as shown in figure 1. The BEA Gross Value Added in finance grew rapidly since 1950 , but there does not appear to be a direct link to the BEA calculation of changes in private fixed assets.

As the financial sector increased in the national product, economists tried to explain how finance could be important in economic growth. These explorations identified several aspects of how finance helps the rest of the economy. Financial institutions can

1. ease the exchange of goods and services,

2. mobilize and pool savings, 
3. facilitate the trading, diversification, and management of risk,

4. monitor investments,

5. exert corporate governance and produce information about possible investments (Levine, 2005; Temin, 2004).

The listed functions of a financial system are quite diverse, and I have numbered them to emphasize that point. The first function can easily be done by a rudimentary financial system, such as having an ancient emperor issue coins. And the second function could be done by savings banks that exist in many agrarian economies. Only when we get lower in the list of functions do we see possible effects of the large financial system we have in the United States today.

While the models of financial effects are illuminating, they typically ignore an important issue. Is finance exogenous to economic growth? Alternatively, is the growth of finance a cause or a result of economic growth? Facilitating economic transactions - number one in the listappears to be an intermediate good or service, not properly thought of as a final good. Perhaps that function should be neglected when recording the others, even though local banks engage in the easiest financial activity to measure.

A small detour into the role of finances in the ancient Roman economy may shed light on this difficult question. The financial sector in the early Roman Empire was well-developed enough for people to quote prices and discuss interest rates in general. There are many times when contemporaries noted that "the" interest rate had increased or decreased. A concrete example comes from Pliny the Younger in the early second century CE when he was governor of a town in Asia Minor. He wrote to Trajan, the emperor, that town revenues were accumulating and that 
the funds were idle. Pliny speculated that the standard interest rate, 9 percent, might be too expensive for private borrowers, and Trajan responded, "I see no other method of facilitating the placing of public money than by lowering the interest [rate].” Both Romans clearly were conscious of how financial markets worked, and Trajan added that he preferred a market outcome (Temin 2013, 174).

Contemporaries noted that loans with extra risk were made at higher than normal ratesnumber 3 on the list -including maritime loans that were higher than normal to compensate lenders for the risk of shipwrecks during the Pax Romana. There were banks all over the Roman Republic and Empire, and inter-bank transfers among them have survived. The financial system of ancient Rome clearly performed the first three functions of finance quite well (Rathbone and Temin, 2008; Temin, 2004).

There also were joint-stock companies to finance trade around the Mediterranean. And there was a financial panic in $33 \mathrm{CE}$. Property values fell sharply, and the government extended cheap credit to potentially defaulting debtors, anticipating both the financial crisis of 2008 and the government's response to it 2,000 years before the Fed began to operate. We can debate how well Roman finances performed the higher functions of finance, but there is little doubt that they engaged in these activities (Kehoe, 1997; Malmendier, 2009; Temin, 2013, chapter 8).

The ancient financial arrangements and understanding did not develop as a result of the factors usually cited for the growth of finance in post-war America. While it is likely that financial sophistication and institutions helped economic growth in ancient Rome, it also appears they were the result of economic growth. One example is not enough to test a possible hypothesis, but it raises the question whether the growth of finance today is an exogenous factor 
that encourages economic growth or a part of economic growth. Rajan and Zingales (2003, 10913) raised this identification problem with more modern evidence, emphasizing how difficult it is.

I now turn to how financial activities enter into the national product today to see if the way we gather statistics on the size of the financial sector relates to these theoretical constructions of the effects of financial activities on other economic activities. I quote a few ways in which the Bureau of Economic Analysis (BEA) explains its procedures to give you a sense of the complications in reducing complex transactions in the finance sector to measures of the national product.

The Bureau of Economic Analysis summarized their procedure in an introduction. "The treatment of proprietaries' income in the accounts is similar to the treatment of corporate profits. In particular, proprietaries' income is included on the left side of the business enterprise income account. Although sole proprietors and partnerships may retain net earnings for future use or investment, a simple accounting convention is used to record the distribution of their income, because of data limitations. In particular, proprietaries' income is treated as being distributed entirely to owners in the household and institutions sector, which is consistent with the tax treatment of such income (US Department of Commerce, 2007, 15)."

The BEA explained how problems might arise in finance: "For example, in financial accounting, corporations sometimes record the value of extraordinary losses before they actually incur the expenses associated with the losses. Financial accounting also allows some flexibility in the way definitions are applied by corporations- for example, in the selection of service lives and in the valuation of assets. In addition, the tax-accounting tabulations are comprehensive, 
covering all incorporated businesses — both publicly traded and privately held — and all industries, while financial-accounting tabulations cover a subset of the corporate universe. However, financial-accounting information is more timely than the tax-return data, so it is used by BEA to derive the estimates for the most recent year and for the current quarters (US Department of Commerce, 2017, p 13-3).”

The BEA summarized its current practice of calculating the output of the financial sector, and specifically of credit intermediation and related activities, the same way as it does for other kinds of firms, that is, by looking at profits: "Receipts less deductions from IRS tabulations of income tax returns, adjusted for understatement of income on tax returns and for conceptual differences (US Department of Commerce, 2017, p. 13-17).”

It is clear that the BEA does not have a comprehensive measure of the output of the financial sector to use as its output. Looking back at the list of five separate functions of a financial system, it is hard to think of a way to do better. The BEA talks frequently about the difference between national product and national income. They must be equal, taking taxes and transfers into consideration. And if they are equal, then it does no harm when calculating national product to use estimates of national income in place of absent data on national product. The BEA publishes an "error" when national income and product do not come out equal (Rassier, 2012).

Nordhaus (2006) and Corrado, Hulten and Sichel (2009) tried to fit financial capital into the NIPA, but they found it very difficult to present a method that came close to the BEA's need to issue quarterly and even more detailed estimates. Nordhaus $(2006,150-51)$ explained why: "The problem in a nutshell is that there are no observable values or prices that are the analogs to 
prices the Bureau of Labor Statistics finds to write down and tabulate. ... Valuation techniques that are largely subjective and based only on survey information alone ... are difficult to validate and should be avoided where possible."

The BEA therefore uses profits as a measure of output, adjusted in a variety of ways to accommodate different industries. It is hard to get more specific without becoming so technical that no outsider can understand what the BEA is doing. Philippon $(2015,1416)$ used an estimate of value added, that is, profits minus wages, in his historical estimate of the size of the financial sector. As he defined it, "I therefore use the GDP share of the finance industry, i.e., the nominal value added of the finance industry divided by the nominal GDP of the US economy."

This is a bit of a problem as profits often are taken as wages, as Piketty (2014) reminded us. The meaning of value added consequently is not as clear in finance as in manufacturing. Which wages are subtracted? Secretaries, if there are any in modern offices, clearly are workers, but the wages of finance people shown in figure 2 clearly are not limited to clerks. The Ushaped curve looks amazingly similar to Piketty's graph $(2014,24)$ that shows the same U-shape for inequality in the United States as a whole, measured as the share of the top income decile. The wages shown in figure 2 are largely coterminous with the value added in finance shown in figure 1 (for the last half-century only). The number of employees only is available for nonsupervisory employees and imputed to all employees; wages in finance may be imputed similarly (Dean and Kunze, 1992).

Education also is shown in Figure 2, and it follows the path of wages. It also raises another identification problem. Do financial people earn high salaries because they have education, or do they get education in order to get financial jobs? Philippon and Reshef (2012) 
concluded after a thorough investigation that education and salaries were jointly determined by changes in financial regulation, as the passage and subsequent repeal of Glass-Steagall Act in 1933 and 1999 caused changes in both education and wages.

Philippon (2015) expressed surprise that his measures indicated that productivity within the financial sector had not changed over a very long time. This appears to represent the way the data were collected rather than any historical fact. If the data on the national product side are the same as the data on the national income side, it is hardly surprising that productivity is stuck at its historical level. Europeans have used something called FISIM to measure the quantity of loans extended by the financial sector. This is only part of the functions listed above, but it is progress. The United States has yet to join them. (FISIM is explained in an Appendix.)

Piketty (2014) disaggregated national income by individuals rather than economic activities as done by the BEA. This seemingly orthogonal decomposition required Piketty to find and process a vast amount of data, and he needed a simple model to support it. He therefore adopted the Solow model to serve that function. Instead of adding new kinds of capital as others had done, he simply assumed that capital and wealth were the same.

Piketty $(2014,47-48)$ added the value of financial assets on various markets to physical capital to get a new expanded estimate of capital, which he then used the same way Solow used physical capital in analyses of economic growth. In Piketty's simple model, as in Keynes' and Solow's original models, there was only a single interest rate. Piketty therefore did not distinguish financial and physical assets and their implications; he assumed they operated in the same ways. His summary of his findings is that inequality grows when $r>g$, where $r$ is the economy's interest rate and $g$ is the economy's growth rate as measured by the BEA. He 
compared his financial interest rate to a physical rate of growth that measures the financial sector by the income of its participants.

Solow (2014) suggested some problems with Piketty's amalgam of capital and wealth: "We know how to calculate the wealth of a person or an institution: you add up the value of all its assets and subtract the total of debts. (The values are market prices or, in their absence, some approximation.) The result is net worth or wealth. In English at least, this is often called a person's or institution's capital. But "capital" has another, not quite equivalent, meaning: it is a "factor of production," an essential input into the production process, in the form of factories, machinery, computers, office buildings, or houses (that produce "housing services"). This meaning can diverge from "wealth." Trivially, there are assets that have value and are part of wealth but do not produce anything: works of art, hoards of precious metals, and so forth. (Paintings hanging in a living room could be said to produce "aesthetic services," but those are not generally counted in national income.) More significantly, stock market values, the financial counterpart of corporate productive capital, can fluctuate violently, more violently than national income." In short, wealth may be capital, but it behaves differently than Keynesian capital. Some kinds of wealth produce services that are not counted in GDP, some kinds are not productive in what we call economic growth, and some kinds fluctuate violently.

Garbellini (2018) adds that wealth does not depreciate like physical capital. That may be true in general, but the use of tax data involves the BEA with our tax laws. Tax laws favor realestate financing, a large part of the Finance Insurance and Real Estate (FIRE) sector. Kushner, the son-in-law of President Trump, managed to accumulate over \$300 million without paying any income tax at all for several years. He accomplished this prodigious feat by taking large deductions for depreciation of his commercial properties. Many people say that the value of 
property is determined by location, location, location, but the IRS allows depreciation for commercial property nonetheless. The value added in finance is increased by its legal depreciation (Drucker and Flitter, 2018).

\section{Intangible investments in general}

I now generalize these observations by considering other service activities. Griliches noted the trend away from manufacturing many years ago, and I build on his work here. $\mathrm{He}$ argued in 1990 that the economy was moving into services, but that our national income and product accounts spent most of its resources on measuring agriculture and manufacturing. $\mathrm{He}$ argued that services were defined as "everything except agriculture, mining, construction, and manufacturing." This negative definition includes the FIRE sector described in the previous section and many other activities.

Griliches argued that the lack of data for services was due to the history of data collection: "Because of this lack of data, a number of service industries series are deflated by makeshift deflators, and real output is assumed to grow proportionately to some measure of input." This was and is true for governmental activities, "and such difficult-to-measure sectors as banking and business services (Griliches, 1990, 6-7).”

The trend has continued in the decades since Griliches wrote. In the absence of good output measures, this can be seen in the allocation of the labor force. The de-industrialization of the US has as its counterpoint the rise of services—-by definition. Agriculture, mining, construction and manufacturing occupied only one-quarter of the labor force in 1990 and fell 
below one-seventh in 2016. The rest of the labor force is working in services (Carter, et al., 2006, United States Department of Labor, 2017).

The BEA acknowledged this problem in 2009: "While all countries account for investment in tangible assets in their gross domestic product (GDP) statistics, no country currently includes a comprehensive estimate of business investment in intangible assets in their official accounts (Aizcorde, Moylan and Robbins, 2009, 10)." The authors noted that the BEA has included some kinds of intangible investments, but they acknowledged that progress was slow. There is a paucity of information, and the BEA has to search for sources of relevant data.

The BEA added R\&D investment as reported to the National Science Foundation after considering how to deflate R\&D for estimates of real GDP. They also added investment in artistic originals into investment by shifting them from current expenses to an investment account (Soloveichik, 2010). And they are conducting research into measuring investments in human capital. They admitted that the measure under study would only include investments in traditional education, not on-the-job training that might be important, and that the measure would focus on market-based investments in education, not individuals' investment of time (Aizcorbe, Moylan and Robbins, 2009, 12).

While the BEA has struggled to measure parts of intangible activities and investment, economists have continued to compare them with physical activities and investment. For example, Corrado, Hulten and Sichel (2009) provided a measure of intangible investment and explored whether it should be considered an intermediate good or an investment. They presented evidence that we are understating economic growth by ignoring intangibles. 
Corrado and Hulten $(2010,103)$ suggested that the question of measuring a technological revolution may be complex. In their words, "You must include a broad range of intangible investments in the analysis, both as inputs and outputs, because they are an essential part of the innovation process and they loom increasingly large in accounting for economic growth.”

The result of implementing this program led to considering computer software, scientific and non-scientific R\&D, brand equity and firm-specific resources. They were measured in various ways and cumulated to find that they increased the estimated growth rate of the non-farm economy by 10-20 percent in recent years. Capital deepening in this expanded form was the principal source of growth in the last half of the twentieth century. And, as intangible investments are owned by companies, the labor share of national income was reduced (Corrado, Hulten and Sichel, 2009).

This work is highly interesting, but it does not extend to financial activity. In this formulation, finance is not a part of intangible investment. It appears to be quite distinct. It is no more physical or tangible than intangible investment, but including finance into GDP appears to pose distinct problems.

A recent book on this topic is entitled Capitalism without Capital. The authors appear to mean capitalism without physical or Keynesian capital, and they do not distinguish human and social capital. While they cite many economists, they do not structure their argument within the augmented Solow growth model. Instead, they try to understand how the intangible economy functions (Haskel and Westlake, 2018).

They argue that intangible investments have four characteristics that distinguish them from physical capital. First, they are scalable. Intangible investments can be scaled up or down 
to organize all kinds of activities. They are like "non-rivalrous" ideas as opposed to physical assets that are "rivalrous" in the sense that if I am using a rivalrous asset, no one else can use it at the same time. Patents and copyrights protect some ideas, but organizational ideas that enable companies to operate well are not covered by these legal restrictions.

This first characteristic of intangible investments is useful for business historians recounting the success and failures of various companies, but it is not specific enough for the BEA to try and measure. The BEA has introduced measures of software investment and is considering adding investments in human capital, but it has not tried to measure organizational development.

Intangible investments are also sunk investments. That is, they are created for particular economic activities and lack resale value if the activities fail to prosper. In other words, there are no markets for used intangible investments. Nordhaus argued that this second characteristic makes it impossible for the BEA to include it in the national product because there are no market prices to observe. That is why organizational development cannot be included in the calculation of investment.

Finally, intangible investments have spillovers and synergies. All economic activities have these characteristics, some more than others. They may have more common with intangible than physical investments, but it is hard to know without measurement. All of these aspects might be considered to be human capital. If so, the distance between Capitalism without Capital from the BEA's plans to include formal schooling as its measure of human capital is clear. Haskel and Westlake raise some important questions about intangible investments but do not advance measurement at all. The BEA's measure however will support the measure of education 
in Figure 2. Philippon and Reshef measured formal education in their graph by showing the proportion of financial employees that had more than a high-school education.

Brynjolfsson, Rock and Syverson (2018) argue that some intangible investments can take their time showing up in productivity. They study general-purpose technologies and conclude that they may require complementary changes in economic activities to be effective. Their study does not tell how to measure these intangible investments. Instead it counsels patience if the effects do not show up immediately.

A widening split in the economics literature is apparent. Most economists focus on $21^{\text {st }}$ century issues and problems, but they test their theories and hypotheses with $20^{\text {th }}$ century data. These economists are hardly secret historians; they unwittingly use contemporary data compiled as if from a $20^{\text {th }}$ century economy. David Brooks, a weekly columnist at the New York Times, revealed how pervasive this split is when he asserted recently: "For the last several decades, American economic policy has been pinioned on one goal: expanding G.D.P. We measure G.D.P. We talk incessantly about economic growth (Brooks, 2018)."

Brooks' lack of information about the measurement of GDP is appalling, but it comes from the way economics is taught in American colleges. College economics education does not bore undergraduate students by taking them into the kitchen to see how the data they use are derived, and graduate students are rushed into considerations of Euler Equations without being told about the problems of measuring intangible investments. Students are told that the economy has de-industrialized, but they have not been made aware how the growing share of services makes the measurement of macroeconomic variables increasingly difficult. 


\section{Eating the Family Cow with Negative Intangible Investments}

Even though we cannot measure intangible investments well in the national income and product accounts, they are important in economic growth. I treat the various kinds of capital listed above separately, starting from Keynesian investment, which can be measured, and ending with social capital that can only be inferred from isolated examples. In between, financial and human capital have some quantification. I divide each section into private and public sections as well. There also are connections between them that illustrate how these divergent forms of capital interact.

This section transitions from the measurement of nation income and product to the application of economists' understanding of the nature of investment. Figure 3 shows the share of Keynesian investment in GDP for roughly the last half century. It fluctuated widely as the economy experiences recessions and prosperity, but it clearly did not return to its previous prosperity level after the 2008 Financial Crisis. Various reasons have been proposed to explain this lack, but no one disputes the low level of Keynesian investment in recent years. Starting the discussion of economic growth with the kind of investment that can be measured sets the pattern for other kinds of investment that cannot be measured as accurately (Alexander and Eberly, 2018).

Public support for physical investment has flagged despite the great need for infrastructure investment. Republicans would not support any Democratic proposals during the Obama presidency. President Trump stressed his intention to invest during his presidential campaign, but no plans emerged during his presidency. It appears that any intention to invest in 
public assets foundered on the rocks of privatization and low taxes (Mayer, 2016; MacLean, 2017; Temin, 2017; Bellafante, 2018).

The Koch brothers extended the fight against public transit to cities and counties across the country. For example, the business community in Nashville, TN, had ample public support for a comprehensive plan to improve the local infrastructure with coordination between plans for light-rail, buses and a traffic tunnel underneath the town center. But house-to-house campaigning against the taxes needed for this plan by the Kochs' Americans for Prosperity organization defeated the plan at a local election. "The Kochs' opposition to transit spending stems from their longstanding free-market, libertarian philosophy. It also dovetails with their financial interests, which benefit from automobiles and highways (Tabuchi, 2018a)."

The result of this neglect is that the American Society of Civil Engineers (2017) gave American infrastructure a $\mathrm{D}^{+}$, repeating the grade in their 2013 report. Bridges retained their $\mathrm{C}+$ grade, but public transit systems received a grade of D-, down from D in 2013. The new report from the civil engineers was very much like their report of four years earlier; the overall picture of an ageing and underfunded infrastructure remains (Temin, 2017).

The lack of infrastructure harms urban growth, but ignoring and denying climate change harms the whole economy. Dramatic reports in late 2018 showed that climate change harms our economy and needs at least as much attention as roads, bridges and subways. Scientists noted that the government was required to release the most comprehensive report; it did so on the day after Thanksgiving to minimize its public impact. The report predicted that climate damage will reduce the American economy by ten percent at century's end if significant steps are not taken to rein in global warming. This startling conclusion grabbed the public press despite the 
administration's efforts to hide it. The report detailed some of the ways climate change would impact the United States economy: \$141 billion from heat-related deaths, $\$ 118$ billion from sealevel rise and $\$ 32$ billion from infrastructure damage by the end of the century, among others (Davenport, 2018; Davenport and Pierre-Louis, 2018).

But while the public was aroused, the federal government rolled back climate protections imposed by the Obama administration. The Koch network and other large oil companies like Marathon Petroleum pushed back on fuel efficiency standards for cars and trucks, which use one quarter of the world's oil. Their advocacy resulted in national presidential directives and draft legislation for states from the American Legislative Exchange Council, another part of the Koch network. The draft described the existing fuel-efficiency rules as "a relic of a disproven narrative of resource scarcity" and says "unelected bureaucrats" shouldn't dictate the cars Americans drive (Tabuchi, 2018b: Levenson, 2018).

Turn now to financial investment, where we find some of the same problems. Rajan and Zingales (2003) argued that finance consistently has been at the mercy of politics. That surely is true, but finance was being deregulated as their book appeared. Deregulation began with airlines and Savings and Loan Associations to deal with stagnation in the 1970s and continued with the repeal of Glass-Steagall in 1999 — both under Democratic administrations — that set the stage for the 2008 financial crisis. There can be too much of a good thing (Warf and Cox, 1996; Winston, 1998). Since the election of 2016, politics puts the interests of large corporations and rich anarchists in charge of financial policies, leading to fiscal and financial policies that help only this part of the population. 
The 2017 tax cut was a substantial financial disinvestment because it increased the national debt of the United States by $\$ 1.5$ trillion or more for the next decade. (Piketty included government debts in his definition of capital.) It will be hard for private financial investment to overcome this negative contribution. And, as shown in figure 2, the share of gross domestic investment is smaller than in recent years. What is going on?

Republicans sold the 2017 tax cut as a refashioning of the incentives in the American economy that would unleash more investment, better efficiency and higher wages, along with enough growth to offset any revenue lost to the government from lower tax rates. That clearly is not happening. Business investments typically are for short-run gains, and changes in the tax rate have little incentive effects. Almost half the tax cut to large corporations and rich individuals went into tax havens to lower taxes even farther. And much of the rest went into stock purchases to raise the stock price and spread the gain among companies' rich friends. Physical investment is likely low because of globalization as well. Businesses are not investing in the old economy because the old products can be imported from advanced developing countries like Japan and China. Our place in this new globalization will depend on some of the intangible investments discussed below, chiefly human capital (Tankersley and Phillips, 2018; Tørsløv, Weir, and Zucman, 2018; Koo, 2018, Chap. 5).

Turning to private financial investment, the effect of finance on growth appears to be non-linear. There are diminishing returns from finance as it gets larger and becomes negative for large financial sectors. International comparisons show that higher growth of the financial sector can reduce economic growth. Credit booms harm industries that have intangible investments or high R\&D intensity because they lack collateral for loans. And the resources that go into finance 
crowd out other economic activities. (Rajan and Zingales, 2003, 31-33; Cecchetti and Kharroubi, 2018).

Private equity firms have grown in recent decades to raise capital from wealthy individuals and institutions to make risky investments that promise high returns. Private equity firms buy companies and use high leverage to make these high returns. The debts, which have fixed interest payments, provide high returns on the capital invested by rich investors since all the profits go to them. And if the company fails, the debts default and investors walk away without loss. Society picks up the tab (Davis, 2009; Foroohar, 2016).

The typical setting is shown by the treatment of Simmons Bedding in a small Wisconsin town. Simmons filed for bankruptcy protection in 2009 as part of an agreement by its current owners to sell the company — the seventh time this 133 year old firm was sold in a little more than two decades — after being owned for short periods by a parade of different private equity firms. Simmons workers lost their jobs (Creswell, 2009).

A larger example is shown by the 2018 bankruptcy of Sears, America's largest retailer. The problems at Sears Holdings, as it is known on Wall Street, were more than a decade in the making, all because a Mr. Lampert stayed convinced of his own deeply flawed thinking. Mr. Lampert began this 15-year odyssey in 2003 after he bought the bonds of the failing discount retailer Kmart and converted those bonds into a controlling position in Kmart's equity. He ran his own hedge fund, ESL, investing money from wealthy billionaires. In 2005, he merged the rejuvenated Kmart with Sears, then a conservatively run thriving nationwide retailer. 
Mr. Lampert decided not to invest the capital needed to refurbish the Sears and Kmart stores to keep their inventory and appearance fresh. Instead, he made a huge gamble that did not pay off to invest in Sears's website and online shopping. But Amazon ate Sears's lunch (and dinner) until Lampert threw in the towel in 2018 and joined forces with Amazon to allow it to sell Kenmore appliances, something that he had long refused to do. Sears workers might find jobs at Amazon. But Sears was an old company that treated its workers well, and Amazon is a new company that is less generous (Cohan, 2018; Schwartz and Corkery, 2018).

Turn now to the third kind of capital, human capital. Teacher pay and state support for public universities have been lagging for decades. Teacher pay was not raised when women were able to get better paying jobs in the 1970s, and public universities lost support after every financial crisis when state expenditures needed to be reduced. The trends now are the continuation of these patterns (Temin, 2002b; National Science Board, 2002).

Betsy DeVos was confirmed as Education Secretary in 2017 by a single vote delivered by the vice president, who was brought in to break the first tie on a cabinet nomination. DeVos's support for charter schools and vouchers that can be used at private, religious and for-profit schools was well known, as was her antipathy toward public schools. Senator Jeff Sessions was confirmed as Attorney General only after the vote on DeVos so that he could create the Senate tie that the vice president broke. Despite this inauspicious beginning, Secretary DeVos has had a longer time in office than many other members of Trump's initial cabinet and personal advisors, revealing that her views and program have the approval of the Republican administration (Huetteman and Alcindor, 2017). 
The first education budget of the new administration in 2017 confirmed the worst views of Congress as it split over DeVos' confirmation. The budget cut over ten billion dollars from federal education initiatives, including work-study programs, loan forgiveness, and mental health. And the budget spent more money to expand charter schools, education vouchers and public-school activities to promote choice-friendly policies. The budget reached down into the details of local school funding to end many programs designed to help the poorest students. The budget stated that it maintained the traditional reliance on evidence-based policies, but it ignored the mixed reviews that charter schools have received (Ravitch, 2017).

DeVos revealed some of her educational philosophy during an unannounced visit to Koch Industries in Wichita, KS, to meet with representatives of Youth Entrepreneurs, a Wichita-based non-profit group founded and funded by Charles and Elizabeth Koch with more than $\$ 1.5$ million. Youth Entrepreneurs provide a high school curriculum designed to inculcate students in the blessings of unfettered capitalism and libertarian ideology. Among the teachings included in the Youth Entrepreneurs lesson plans and classroom materials are that "the minimum wage hurts workers and slows economic growth. Low taxes and less regulation allow people to prosper. Public assistance harms the poor. Government, in short, is the enemy of liberty." Youth Entrepreneurs aim to "inoculate" students against liberal ideas by assigning them to read passages from socialist and Marxist writers, whom they call "bad guys." These readings are compared to works by the "good guys" — free-market economists like Friedrich Hayek and Ludwig von Mises (Bryant, 2018; MacLean, 2017; Wilkie and Resmovits, 2017).

All the while, teacher pay declines relative to other similar jobs. Macroeconomic thinkers say that education is the key to national success in the world where developing countries 
like China and Japan challenge United States economic leadership. Letting our human capital decay may be the most important problem for future generations (Allegretto and Michel, 2018; Koo, 2008, Chap. 5).

Finally, turn to social capital. This is a new name for the old idea of community, and it has spread through the social sciences. No way has been found to include it in GDP, and the BEA has its hands full trying to put an imperfect measure of human capital into our national accounts, as noted above. Various proxies have been introduced to add social capital into growth theory and to note whether it appears to be increasing or decreasing. A few examples show what has been happening recently to American social capital.

Starting with public changes, consider the effects of mass incarceration, which has grown to the point where we look more like the autocratic regimes of Eastern Europe and the Middle East than the democracies of Western Europe. The recent stability in the number of American prisoners indicates that we have settled into a new equilibrium of mass incarceration, and it will be hard to dislodge ourselves from this apparent equilibrium (Temin, forthcoming).

Criminologist Todd Clear $(2007,175)$ noted that young, poor and dominantly minority men and (to a lesser extent) women cycle through jails, prisons and then back into the community. They disrupt families, weaken social networks and other forms of social support, putting children at risk and promoting delinquency. The collateral effects of these high rates of incarceration contribute to more crime that fuels a public call for ever-tougher responses to crime. The increasing presence of people of color contributes to a public sense that race and crimes are closely linked, sustaining an ever-growing policy base that guarantees new supplies of penal subjects in a self-sustaining and self-justifying manner. 
In both financial and social capital investment, diminishing and even reversal of returns are becoming clear. At lower levels of financial investment, the results are beneficial to national income and product, but they decrease until they now are doing more harm than good for most people. Similarly, incarceration helps keep order for ordinary people, but mass incarceration destroys social capital. There is a self-reinforcing pressure here where participants in finance and in criminal justice and private prisons acquire what they consider property rights to their activities and resist limits on their growth.

Turning to private social capital, these government actions were echoed in the 1970s by business schools that adopted new principles that became the basis of business thinking. This transformation was stimulated by two finance articles. Fama (1970) and Jensen and Meckling (1976) argued that financial markets were efficient and that managers should be linked to the market more than to production. This focus on finance led them to regard excess taxes and regulations as a danger to American efficiency and human costs of economic activity as irrelevant. Pearlstein $(2018,137)$ took issue with this framework and proposed a new "Pearlstein graph." Patterned after the Laffer curve, the Pearlstein graph showed efficiency increasing with inequality at low levels of inequality, but decreasing with too much inequality. The result is an upside-down $\mathrm{U}$ that shows we could enjoy the most efficiency with more equality of income. Wu $(2018,70)$ drew this relation as a right-side $\mathrm{U}$ by graphing costs. Pearlstein and Wu concluded that business schools and now businessmen produced a kind of capitalism that corrodes social capital by undermining trust and discouraging socially cooperative behavior. Business focus on economic efficiency destroys social capital. Like modern finance and mass incarceration, too much emphasis on efficient firms makes the economy work worse, not better. 
Social capital also is destroyed every time there is a mass shooting in the United States. The FBI reports that hate crimes increased for the third year in 2017, and easy access to guns has made many of these crimes lethal. Crazy people have been allowed to express their anger by shooting up churches and schools with alarming frequency. They are not helped by administration comments that churches and schools should have armed guards to protect themselves or by National Rifle Association (NRA) claims that the Second Amendment should apply to all. Just as the Supreme Court weaponized the First Amendment, the NRA literally has weaponized the Second (Eligon, 2018; Goodstein, 2018).

Gun violence has been turned toward places where people congregate: churches, synagogues and — most notably—schools. Students cannot learn, that is, cannot acquire human capital, while using their attention to avoid suffering from gun-toting madmen. Yet the NRA position parroted by many politicians is to advocate arming teachers and schools to prevent violence—-further distracting students from their education (Mazzei, 2018).

Dasgupta (2007) succinctly defined social capital as the confidence that contracting parties will fulfill their contracts, which is a result of belonging to a community. He argued in his Very Short Introduction to modern economics that social capital was the primary factor differentiating the prospects of ten year old girls living in the American Midwest and in southern Ethiopia. Ordinary children growing up in the United States today may be very adversely affected by the lack of social capital—which has been declining for several generations.

Putnam (2000) and Costa and Kahn (2003) attributed this decline to TV, working women, and growing economic inequality. Rae (2003) added the demise of the pedestrian urban shopping core in American cities. The assault on social capital by the government and the 
business establishment, if not checked soon, will make a very inhospitable environment for our children and grandchildren to grow up into.

\section{Conclusion}

The Solow growth model stimulated research to uncover new sources of economic growth. Economists added human, social and financial investment to Keynesian investment. These contributions added to our information and understanding, but they pose difficult problems for national income and product accounting.

I listed the variety of functions that finance serves for the economy and described how difficult it has been for the BEA to construct measures to show this contribution to the national product. In the absence of a suitable proxy, the BEA has adopted the usual practice of imputing

the output of finance from how much income the financial community gets from being employed in finance. Recent research finds that finance has grown to the point where it no longer continues to benefit the entire economy, but it instead increases the incomes of the richest Americans at the expense of everyone else.

The BEA approach to other intangible kinds of capital and investment has followed the lead of its treatment of finance. Where a few proxies have been inserted into investment in the national product, the bulk of intangible investment is inferred from the income earned by companies and individuals. The BEA is working actively to improve the proxies by which it imputes intangible investment to the national product, but it has a long way to go to adequately account for the probable size of intangible investment in our service economy. 
Since a rising proportion of investment is imputed rather than observed, it is increasingly hard to know whether the capital stock is expanding or contracting. The evidence shown here reveals that we are investing less than before in Keynesian investment of private fixed assets and dis-investing other forms of capital. Financial investment is negative due to rapidly rising government debt and private financial investments that redistribute income toward the top end of the income distribution. Investments in human and social capital—both outside the BEA's methodology—clearly are negative.

This erosion of human and social capital does not appear in the NIPA, but it is very important for future economic growth. Without robust human capital and social capital, the American economy will be unable to grow. Hall and Jones (1999) — updated — and the Social Progress Index (2018) may provide better indices of where the American economy is going than GDP. They reveal that if investment in human and social capital does not recover soon, our future could be like Argentina's past as it went from one of the richest countries after the Second World War to a poor country subject to periodic crises today. This decline was a result of bad policies that came in turn from a fractured society and divisive politics (Lewis, 2009. 19-34, 19192). 


\section{Appendix}

As noted in the text, the BEA only imputes a measure of financial services. This is not as large as the imputation of rent for owner-occupied houses, but it is still large: "Another large imputation is that made to account for services (such as checking-account maintenance and loan services to borrowers) provided by banks and other financial institutions without charge or for a small fee that does not reflect the entire value of the service.” (BEA, 2017, 2-5.)

FISIM, Financial Intermediation Services Indirectly Measured, is a measure of the output of the financial services that is used in the European National System of Accounts, but not in the United States. The output of financial services is measured by the margin between the interest rates applied to borrowers and savers. One method of calculating it is as the total property income receivable by financial intermediaries minus their total interest payable, excluding the value of any property income receivable from the investment of their own funds, as such income does not arise from financial intermediation. While FISIM represents an attempt to measure the second and third items in the list of financial functions, it abandons the effort to have a comprehensive measure of output for the FIRE sector. And it only measures the output in those two areas indirectly.

FISIM is described in a 2010 report by London School of Economics: "To measure the value of financial services embedded in interest rate margins, the concept of FISIM - Financial Intermediation Services Indirectly Measured - has been developed internationally. The concept itself was introduced in the 1993 update of the United Nations System of National Accounts (SNA). ... FISIM is estimated for loans and deposits only. The calculation is based on the difference between the effective rates of interest (payable and receivable) and a "reference" rate 
of interest, multiplied by the stock of outstanding balances. According to SNA guidelines, this reference rate represents the pure cost of borrowing funds - that is, a rate from which the risk premium has been eliminated to the greatest extent possible, and that does not include any intermediation services (Haldane, Brennan and Madouros, 91-92; Haldane, 2010).”

In more contemporary terms, FISIM takes its cue from the Capital Asset Pricing Model that measures the return on a specific asset as the difference between the interest rate returned by that asset and a risk-free interest rate. The risk-free rate normally is given by the return on United States Treasury bills. The return on these bills is thought of as the most risk free of any interest rate in the world. There is no comparable measure for equity holdings.

A 2015 BEA summary of the differences between the US NIPA and the European SNA did not mention FISIM (McCulla, Moses and Moulton, 2015). 
Figure 1

Gross Value Added in Finance

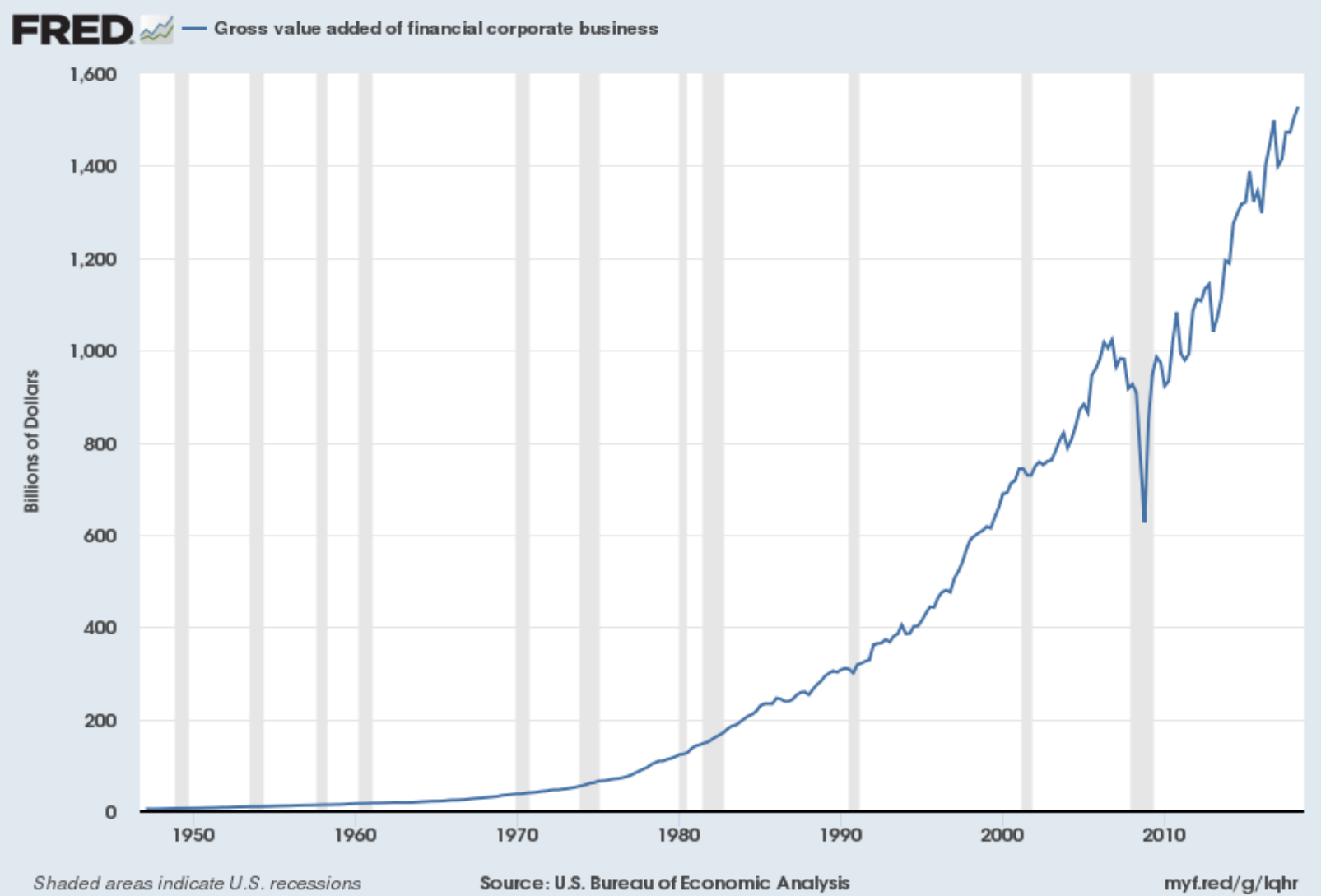

Source: U.S. Bureau of Economic Analysis, Gross value added of financial corporate business [A454RC1Q027SBEA], retrieved from FRED, Federal Reserve Bank of St. Louis; https://fred.stlouisfed.org/series/A454RC1Q027SBEA, October 21, 2018. 
Figure 2

Relative Wage and Education in Finance

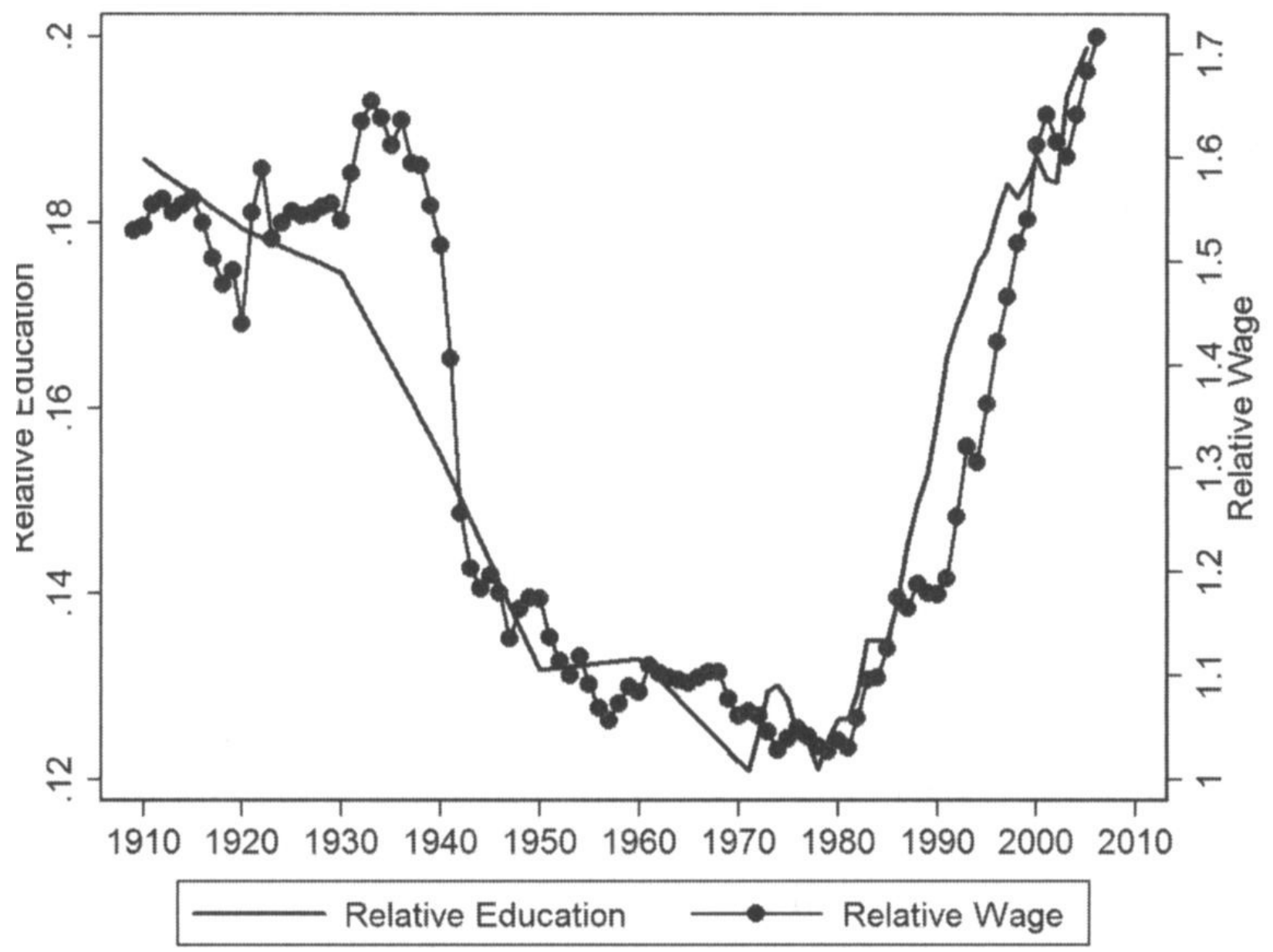

Source: Philippon and Reshef, 2012. 


\section{Figure 3}

Gross Domestic Investment as a share of GDP

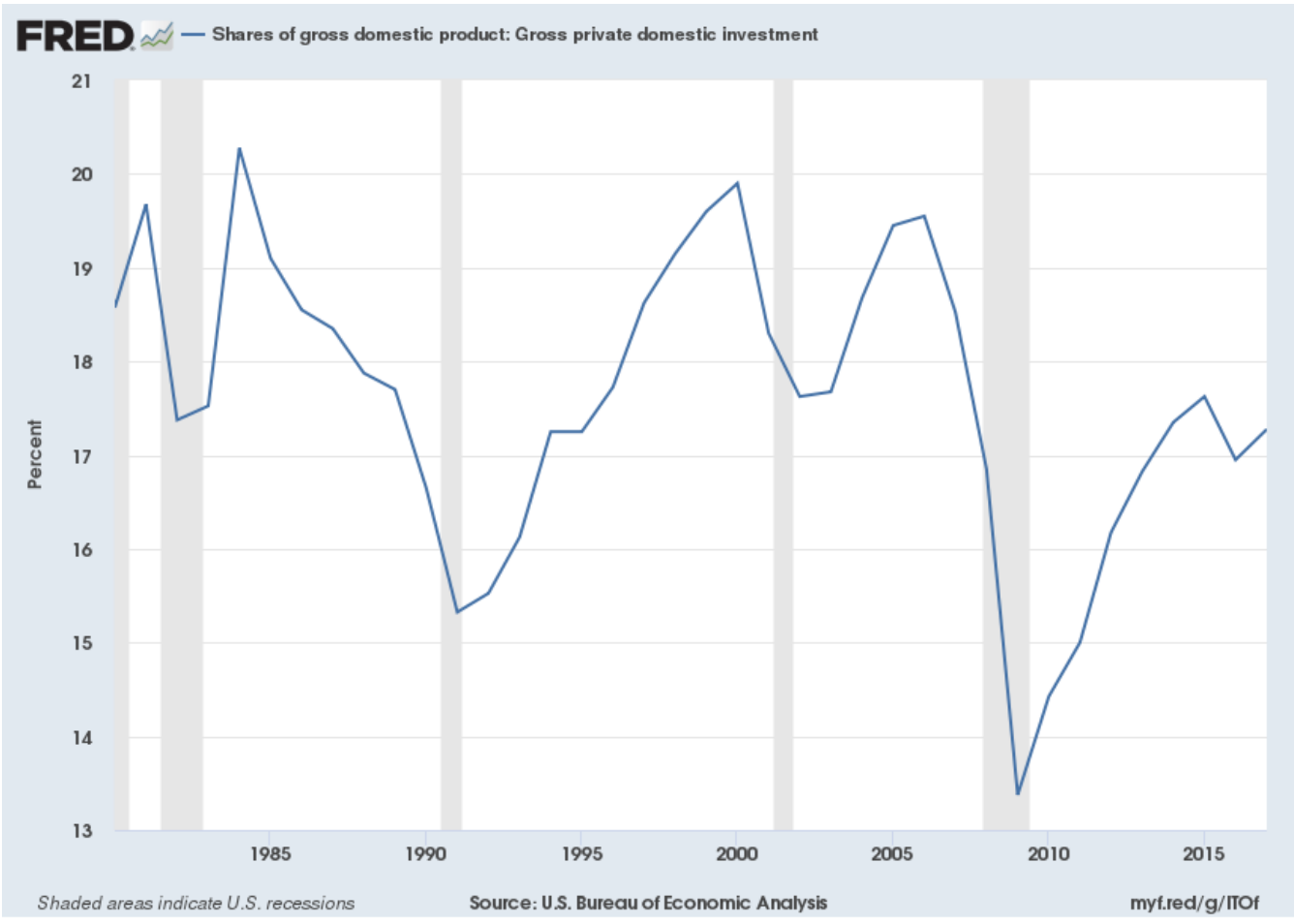

Source: Source: U.S. Bureau of Economic Analysis, Shares of gross domestic product: Gross private domestic investment [A006RE1Q156NBEA], retrieved from FRED, Federal Reserve Bank of St. Louis; https://fred.stlouisfed.org/series/A006RE1Q156NBEA, November 5, 2018. 


\section{References}

Aizcorbe, Ana M., Carol E. Moylan, and Carol A. Robbins. 2009. "Toward Better Measurement of Innovation and Intangibles," BEA Briefing, January.

Allegretto, Sylvia, and Lawrence Michel. 2018. “The Teacher Pay Penalty Has Hit a New High.” Economic Policy Institute, September. Available at: epi.org/153196 or https://www.epi.org/publication/teacher-pay-gap-2018/

Alexander, Lewis, and Janice Eberly. 2018. “Investment Hollowing Out.” IMF Economic Review 66 (1). Available at SSRN: https://ssrn.com/abstract=3162101 or http://dx.doi.org/10.1057/s41308-017-0044-2

American Society of Civil Engineers. 2017. 2017 Infrastructure Report Card. Reston, VA: ASCE Foundation.

Bellafante, Ginia. 2018. "Maybe It's Not Taxes That Scare Off Business but Failing Subways." New York Times, December 13.

Brooks, David. 2018. "What the Working Class Is Still Trying to Tell Us.” New York Times, Nov. 8.

Bryant, Jeff. 2018. “How Betsy DeVos Does the Koch Brothers’ Bidding.” OurFuture.org, November, 28. Available at: https://ourfuture.org/20181128/devos-does-koch-brothersbidding?link id=4\&can id=61205f6cb6c240d82da67d5c48a2f959\&source=emailprogressive-breakfast-how-betsy-devos-does-the-koch-brothersbidding\&email_referrer=email_460011\&email_subject=progressive-breakfast-howbetsy-devos-does-the-koch-brothers-bidding 
Brynjolfsson, Erik, Daniel Rock and Chad Syverson. 2018. “The Productivity J-Curve: How Intangibles Complement General Purpose Technologies," National Bureau of Economic Research Working Paper 25148.

Carter, Susan B., et al. 2006. Historical Statistics of the United States New York: Cambridge University Press.

Cecchetti, Stephen G., and Enisse Kharroubi. 2018. "Why Does Credit Growth Crowd Out Real Economic Growth?” National Bureau of Economic Research Working Paper 25079.

Clear, Todd R. 2007. Imprisoning Communities: How Mass Incarceration Makes Disadvantaged Neighborhoods Worse. New York: Oxford University Press.

Cohan, William D. 2018. “The Billionaire Who Led Sears Into Bankruptcy Court.” New York Times, Oct. 16.

Corrado, Carol A., and Charles R. Hulten. 2010. "Measuring Intangible Capital: How Do You Measure a 'Technological Revolution?”' American Economic Review: Papers and Proceedings 100: 99-104.

Corrado, Carol A., Charles R. Hulten and Daniel Sichel. 2009. "Intangible Capital and U.S. Economic Growth.” Review of Income and Wealth 55 (3): 661-85.

Costa, Dora L., and Matthew E. Kahn. 2003. "Understanding the American Decline in Social Capital." Kyklos 56 (1): 17-46.

Coyle, Diane. 2014. GDP: A Brief but Affectionate History. Princeton: Princeton University Press.

Creswell, Julie. 2009. "Profits for Buyout Firms as Company Debt Soared.” New York Times, Oct. 4. 
Dasgupta, Partha. 2007. Economics: A Very Short Introduction. Oxford: Oxford University Press.

Davis, Gerald F. 2009. Managed by the Markets: How Finance Reshaped America. New York: Oxford University Press.

Davenport, Coral. 2018. "Major Climate Report Describes a Strong Risk of Crisis as Early as 2040." New York Times, Oct. 7.

Davenport, Coral, and Kendra Pierre-Louis. 2018. "U.S. Climate Report Warns of Damaged Environment and Shrinking Economy." New York Times, Nov. 23.

Dean, Edwin R., and Kent Kunze. 1992. "Prductivity Measurement in Service Industries.” In Zvi Grilishes (ed.). Output in the Service Sectors. Chicago: University of Chicago Press, 73107.

Drucker, Jesse, and Emily Flitter. 2018. "Kushner Likely Paid No Federal Income Taxes for Years, Documents Show.” New York Times, Oct. 13.

Eligon, John. 2018. "Hate Crimes Increase for the Third Consecutive Year, F.B.I. Reports." New York Times, November 13.

Fama, Eugene. 1970. "Efficient Capital Markets: A Review of Theory and Empirical Work." Journal of Finance, 25 (2): 383-417.

Foroohar, Rana. 2016. Makers and Takers: How Wall Street Destroyed Main Street. New York: Crown Business. 
Garbellini, Nina. 2018. "Inequality in the 21st century: A critical analysis of Piketty's work." Institute for New Economic Thinking, Working Paper 69.

Golden, Claudia, and Lawrence F. Katz. 2008. The Race between Eduction and Technology. Cambridge, MA Harvard University Press.

Goodstein, Laurie. 2018. "There is Still So Much Evil: Growing Anti-Semitism Stuns American Jews." New York Times, October 29.

Griliches, Zvi (ed.). Output Measurement in the Service Sectors. Chicago: Chicago University Press, 1990.

Griliches, Zvi. 1994. "Productivity, R\&D, and the Data Constraint." American Economic Review, 84 (1): 1-23.

Haldane, Andrew, Simon Brennan and Vasileios Madouros. 2010. "What is the Contribution of the Financial Sector? Miracle or Mirage." in Turner, Aldane, et al, The Future of Finance: The LSE Report. London: London School of Economics and Political Science, $187-220$.

Haldane, Andrew. 2010. "What is the Contribution of the Financial Sector? Miracle or Mirage." Bank of International Settlements Review, 95/2010 (July 14).

Hall, Robert E., and Charles I. Jones. 1999. "Why Do Some Countries Produce So Much More Output per Worker than Others?" Quarterly Journal of Economics, 83-116.

Haskel, Jonathan, and Stian Westlake. 2018. Capitalism without Capital: The Rise of the Intangible Economy. Princeton: Princeton University Press. 
Heckman, James, Rodrigo Pinto, and Peter Savelyev. 2013. "Understanding the Mechanisms Through Which an Influential Early Childhood Program Boosted Adult Outcomes.” American Economic Review, 103 (6): 2052-2086.

Huetteman, Emmarie, and Yamiche Alcindor. 2017. “Betsy DeVos Confirmed as Education Secretary: Pence Breaks Tie.” New York Times, February 7.

Jensen, Michael C., and William H. Meckling. 1976. "Theory of the Firm: Managerial Behavior, Agency Costs and Ownership Structure.” Journal of Financial Economics 3: 305-360.

Kehoe, Dennis P. 1997. Law and the Rural Economy in the Roman Empire. Ann Arbor, MI: University of Michigan Press.

Keynes, John Maynard. 1936. The General Theory of Employment, Interest and Money. (ondon: Macmillan.

Keynes, John Maynard. 1940. How to Pay for the War. London: Macmillan.

Koo, Richard C. 2018. The Other Half of Macroeconomics and the Fate of Globalization. Chichester, UK: Wiley.

Kuznets, Simon. 1937. "National Income and Its Composition; Discussion between Simon Kuznets, Clark Warburton and M.A. Copeland.” In Studies in Income and Wealth series. Vol. 1. New York, NY: National Bureau of Economic Research.

Levenson, Thomas. 2018. "'Reasonable doubt' on climate change is killing the planet." Boston Globe, December 12. 
Levine, Ross. 2005. "Finance and Growth: Theory and Evidence.” In Handbook of Economic Growth Vol 1, Part A: 865-934. Amsterdam: Elsevier.

Lewis, Paul H. 2009. The Agony of Argentine Capitalism: From Menem to the Kirchners. Santa Barbara, CA: Praeger.

MacLean, Nancy. 2017. Democracy in Chains: the Deep History of the Radical Right's Stealth Plan for America. New York: Viking.

Malmendier, Ulrike. 2009. "Law and Finance 'at the Origin." Journal of Economic Literature 47: 1076-1108.

Mankiw, N. Gregory, David Romer and David N. Weil. 1992. "A Contribution to the Empirics of Economic Growth.” Quarterly Journal of Economics 107 (2): 407-37.

Mazzei, Patricia. 2018. "Back-to-School Shopping for Districts: Armed Guards, Cameras and Metal Detectors." New York Times, Aug. 11.

Mayer, Jane. 2016. Dark Money: The Hidden History of the Billionaires Behind the Rise of the Radical Right. New York: Doubleday.

National Science Board. 2012. "Diminishing Funding and Rising Expectations: Trends and Challenges for Public Research Universities.” A Companion to Science and Engineering Indicators. Available at: https://www.nsf.gov/nsb/sei/companion2/files/nsb1245.pdf

Nordhaus, William D. 2006: "Principles of National Accounting for Nonmarket Accounts." In Dale Jorgenson, J. Steven Landefeld, and William D. Nordaus (eds). A New Architecture of the U.S. National Accounts. Chicago: University of Chicago Press, 143-160. 
Pearlstein, Steven. 2018. Can American Capitalism Survive? Why Greed is Not Good, Opportunity is Not Equal, and Fairness Won't Make us Poor. New York: St. Martin's.

Philippon, Thomas. 2015. "Has the US Financial Industry Become Less Efficient? On the Theory and Measurement of Financial Intermediation.” American Economic Review 105 (4), 1408-1438.

Philippon, Thomas, and Ariell Reshef. 2012. "Wages and Human Capital in the U. S. Financial Industry: 1909-2006." Quarterly Journal of Economics 127 (4): 1551-1609.

Piketty, Thomas. 2014. Capital in the Twenty-First Century. Cambridge, MA: Harvard University Press.

Pilling, David. 2018. The Growth Delusion: Wealth, Poverty, and the Well-Being of Nations. New York: Tim Dugan Books.

Putnam, Robert D. 1993. Making Democracy Work: Civic Tradition in Modern Italy. Princeton: Princeton University Press.

Putnam, Robert D. 2000. Bowling Alone: The Collapse and Revival of American Community. New York: Simon and Shuster.

Rae, Douglas W. 2003. City: Urbanism and Its End. New Haven: Yale University Press.

Rajan, Raghuram G., and Luigi Zingales. 2003. Saving Capitalism from the Capitalists: Unleashing the Power of Financial Market to Create Wealth and Spread Opportunity. New York: Crown Business. 
Rassier, Dylan G. 2012. "The Role of Profits and Income in the Statistical Discrepancy." Survey of Current Business, February.

Rathbone, Dominic, and Peter Temin. 2008. "Financial intermediation in 1st-century AD Rome and 18th-century England." in Koen Verboven, et al. (eds.), Bankers, Loans and Archives in the Ancient World (Leuven: Studia Hellenistica 44: 371-419.

Ravitch, Diane. 2017. "The Demolition of American Education.” New York Review of Books Daily, June 5. Available at: https://www.nybooks.com/daily/2017/06/05/trump-devosdemolition-of-american-education/

Schwartz, Nelson D., and Michael Corkery. 2018. "When Sears Flourished, So Did Workers. At Amazon, It's More Complicated.” New York Times, Oct. 23.

Social Progress Index 2018. Available at: https://www.socialprogress.org/

Soloveichik, Rachel H. 2010. “Artistic Originals as a Capital Asset.” American Economic Review 100 (2): 110-114.

Solow, Robert M. 1956. "A Contribution to the Theory of Economic Growth.” Quarterly Journal of Economics 70: 65-94.

Solow, Robert M. 1957. "Technical Change and the Aggregate Production Function.” Review of Economics and Statistics 39: 312-20.

Solow, Robert M. 2014. “Thomas Piketty Is Right: Everything you need to know about 'Capital in the Twenty-First Century." New Republic, April 29. 
Tabuchi, Hiroko. 2018a. "How the Koch Brothers Are Killing Public Transit Projects Around the Country." New York Times, June 19.

Tabuchi, Hiroko. 2018b. “The Oil Industry’s Covert Campaign to Rewrite American Car Emissions Rules.” New York Times, Dec. 13.

Tanenhaus, Sam. 2018. “'I'm Tired of America Wasting Our Blood and Treasure"”: The Strange Ascent of Betsy DeVos and Erik Prince.” Vanity Fair, September 6.

Tankersley, Jim, and Matt Phillips. 2018. “Trump's Tax Cut Was Supposed to Change Corporate Behavior. Here's What Happened.” New York Times, Nov. 12.

Temin, Peter. 2002a. “The Golden Age of Economic Growth Reconsidered.” European Review of Economic History 6: 3-22.

Temin, Peter. 2002b. “Teacher Quality and the Future of America.” Eastern Economic Journal 28: $285-300$.

Temin, Peter. 2004. "Financial Intermediation in the Early Roman Empire." Journal of Economic History 64: 705-33.

Temin, Peter. 2013. The Roman Market Economy. Princeton: Princeton University Press.

Temin, Peter. 2017. The Vanishing Middle Class: Prejudice and Power in a Dual Economy. Cambridge: MIT Press.

Temin, Peter. Forthcoming. "The Political Economy of Mass Incarceration: An Analytical Model," International Journal of Political Economy. 
Temin, Peter, and David Vines. 2013. The Leaderless Economy: Why the World Economic System Fell Apart and How to Fix It. Princeton: Princeton University Press.

Temin, Peter, and David Vines. 2014. Keynes: Useful Economics for the World Economy. Cambridge, MA: MIT Press.

Tørsløv, Thomas R., Ludvig S. Weir, and Gabriel Zucman. 2018. "The Missing Profits of Corporations." National Bureau of Economic Research, Working Paper 24701.

US Department of Commerce, Bureau of Economic Analysis. 2007. "An Introduction to the National Income and Product Accounts," Methodologies papers, September.

US Department of Commerce, Bureau of Economic Analysis. 2017. NIPA Handbook: Concepts and Methods of the U.S. Income and Product Accounts. Available at: https://www.bea.gov/resources/methodologies/nipa-handbook

US Department of Labor, Bureau of Labor Statistics. 2017. "Employment by Major Industry Sector." Available at https://www.bls.gov/emp/tables/employment-by-major-industry$\underline{\text { sector.htm }}$

Warf, Barney, and Joseph C. Cox. 1996. "Spatial Dimensions of the Savings and Loan Crisis." Growth and Change 27 (2): 135-155.

Wilkie, Christina, and Joy Resmovits. 2017. "Koch High: How The Koch Brothers Are Buying Their Way Into The Minds Of Public School Students.” Huffington Post, Updated Dec 6. Available at: https://www.huffingtonpost.com/2014/07/16/koch-brotherseducation n $5587577 . \mathrm{html}$ 
Winston, Clifford, "U.S. Industry Adjustment to Economic Deregulation." Journal of Economic Perspectives 12 (3): 89-110.

Wu, Tim. 2018. The Curse of Bigness: Antitrust in the New Golden Age. New York: Columbia Global Reports. 